\title{
Kode Etik dan Integritas Guru PAI dalam Perspektif Islam
}

\author{
Anjelina $^{1}$, Mohamad Faisal Aulia ${ }^{2}$ \\ Institut Agama Islam Riyadlotul Mujahidin Ngabar, 2UIN Sunan Gunung Djati Bandung. \\ Email: linaangelina029@gmail.com, faisalkupang1996@gmail.com
}

\section{Abstract}

Penelitian ini bertujuan untuk mengetahui kode etik dan integritas guru PAI dalam perspektif islam. Guru merupakan salah satu faktor penentu keberhasilan dalam pendidikan. Metode yang digunakan dalam penelitian ini adalah metode pendekatan normative yuridis yang dilakukan dengan cara menelaah dan menginterpretasikan hal-hal yang bersifat teoritis menyangkut kode etik, kedudukan yang berkaitan dengan guru Pendidikan Agama Islam. Jenis penelitian yang digunakan adalah peneltian kajian Pustaka (library research). Hasil pembahasan dalam penelitian ini dapat dikemukakan bahwa "Kedudukan guru yang istimewa, ternyata berimbang dengan tugas dan tanggungjawabnya yang tidak ringan." Seorang guru agama bukan hanya guru, tapi juga pendidik. Sebagai pendidik, guru memiliki kewajiban untuk mencapai tujuan pendidikan Islam, yaitu memberikan peran maksimal kepada siswa dan menjadikan mereka muslim yang sempurna. Untuk mencapai tujuan tersebut, guru harus bekerja keras dengan berbagai cara, seperti mengajar, melatih, membiasakan, memberi teladan, memberi semangat, pujian, hukuman bahkan doa. Profesi guru tidak hanya pengetahuan teknis dan manajemen, tetapi juga sikap. Guru hendaknya mengajar dengan niat mengharapkan ridha Allah SWT, menyebarkan ilmu, menegakkan kebenaran. Guru hendaknya tidak menolak untuk mengajar murid yang 
tidak mempunyai niat tulus dalam belajar. Guru hendaknya mencintai muridnya seperti ia mencintai dirinya sendiri.

Keywords: Kode Etik, Pendidikan Islam

\section{A. Pendahuluan}

Guru merupakan salah satu penentu keberhasilan pendidikan. Di lembaga pendidikan Islam di Indonesia, guru disebut ustadz dalam bahasa Arab yang berarti guru atau guru besar. Istilah ustadz sering digunakan dalam pendidikan Islam formal, dimana sistem pendidikan diselenggarakan di Madrasah. Siapapun yang memiliki pengetahuan dapat menyiratkan nilai-nilai yang relevan (dalam hal pengetahuan) dan dapat menjadi pendidik agama Islam. Guru bukan hanya sebuah profesi, tetapi juga profesi khusus, harus memiliki pengetahuan profesional, rasa tanggung jawab dan rasa memiliki. Guru juga memiliki keterampilan dan pengetahuan dasar yang diperlukan. ${ }^{1}$

Dalam Islam citra guru (agama) sangat strategis. Selain menjalankan misi keilmuan agar peserta didik menguasai ilmu agama, guru juga memenuhi tugas sakral, misi kenabian yaitu membimbing dan membimbing siswa di jalan Allah SWT. Peran strategis tersebut tentunya tidak mudah menjadi seorang ustadz. Selain itu, dalam menjalankan tugasnya, ustadz akan menghadapi tantangan yang cukup berat, baik tantangan internal (terkait agama dan materi pribadi guru) maupun tantangan eksternal (terkait dengan kepedulian orang tua, lingkungan yang buruk, dan perkembangan ilmu pengetahuan dan teknologi yang menghasilkan efek negatif dan positif.

\footnotetext{
${ }^{1}$ Imam Rohani, Kajian Kebijakan Pendidikan dalam Undang-Undang Sistem Pendidikan Nasional. Tarbawi Ngabar: Jurnal of Education, 1(01), 2020, hal. 80-99.
} 


\section{B. Metode Penelitian}

Metode yang digunakan dalam penelitian ini ialah metode pendekatan normatif yuridis yang dilakukan dengan cara menelaah dan menginterpretasikan hal-hal yang bersifat teoritis menyangkut kode etik, kedudukan yang berkaitan dengan guru Pendidikan agama islam. Jenis penelitian yang digunakan adalah peneltian kajian Pustaka.

\section{Pembahasan}

1. Kedudukan guru PAI dalam perspektif Islam

Dalam Kamus Besar Bahasa Indonesia, pengertian guru adalah orang yang pekerjaannya (hidup, profesional) adalah mengajar. ${ }^{2}$ Dalam dunia pendidikan, sebutan guru dikenal sebagai pendidik dalam jabatan. Pendidik jabatan yang dikenal banyak orang adalah guru, sehingga banyak pihak mengidentikkan pendidik dengan guru. Sebenarnya banyak spesialisasi pendidik baik dalam arti teoritisi maupun praktisi yang pendidik tapi bukan guru. ${ }^{3}$

Peran dan tanggung jawab guru dalam proses pendidikan sangat berat. Mereka adalah para profesional yang memiliki misi untuk menyampaikan ilmu dan nilai kepada siswa, namun pada tataran praktis sebagian guru masih menganggap bahwa profesi guru sangat sederhana, sehingga mereka tidak terlalu serius dalam menjalankan profesinya. ${ }^{4}$ Misalnya, dalam beberapa kasus, guru hanya

2 Tim Redaksi, Kamus Besar Bahasa Indonesia, (Jakarta: Pusat Bahasa Departemen Pendidikan Nasional-Balai Pustaka, 2005), hal. 377

${ }^{3}$ Noeng Muhadjir, Ilmu Pendidikan dan Perubahan Sosial; Teori Pendidikan Pelaku Sosial Kreatif (Yogyakarta : Rake Sarasin, 2000), hal. 73.

${ }^{4}$ Tety Marzukhoh dan Mahasri Shobahiya, Studi Komparatif Profil Guru Pendidikan Agama Islam Dalam Perspektif Hasan Langgulung Dan Syed Muhammad Naquib Al-Attas, SUHUF, Vol. 29, No. 1, Mei 2017, hal. 39. 
dapat berperan sebagai transfer pengetahuan atau transfer pengetahuan, tetapi tetap tidak dapat mentransfer nilai kepada siswa. Ini adalah masalah serius dalam pendidikan. Ini terutama benar jika dalam konteks pendidikan Islam. ${ }^{5}$

Kedudukan guru dalam Islam sangat istimewa. Dalam Islam, status guru satu tingkat lebih rendah dari pada nabi dan rasul. Ini karena guru selalu berhubungan dengan sains, dan Islam memang menghargai ilmu pengetahuan. ${ }^{6}$ Banyak dalil naqli yang menunjukkan hal tersebut. Misalnya Hadits yang diriwayatkan Abi Umamah berikut:

"Sesungguhnya Allah, para malaikat, dan semua makhluk yang ada di langit dan di bumi, sampai semut yang ada di liangnya dan juga ikan besar, semuanya bersalawat kepada mu'allim yang mengajarkan kebaikan kepada manusia" (HR. Tirmidzi).

Tingginya kedudukan guru dalam Islam, menurut Ahmad Tafsir, tak bisa dilepaskan dari pandangan bahwa semua ilmu pengetahuan bersumber pada Allah, sebagaimana disebutkan dalam Surat al-Baqarah ayat 32:

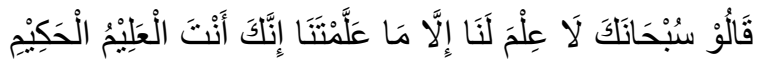

"Mereka menjawab, "Mahasuci Engkau, tidak ada pengetahuan bagi kami selain dari apa yang telah Engkau ajarkan kepada kami. Sesungguhnya Engkau Maha Mengetahui (lagi) Maha Bijaksana."

Karena ilmu datang dari Allah, guru pertama adalah Allah. Pandangan ini telah melahirkan sikap di kalangan

${ }^{5}$ Ibid

${ }^{6}$ Ahmad Tafsir, Ilmu Pendidikan dalam Perspektif Islam, (Bandung: PT Rosdakarya, 2004), hal. 76. 
umat Islam bahwa ilmu tidak lepas dari Allah, begitu pula ilmu tidak dipisahkan dari guru. Sebab, status guru dalam Islam sangat tinggi. Alasan lain mengapa guru menikmati status tinggi dalam Islam terkait dengan kewajiban belajar setiap Muslim. Proses pembelajaran dilakukan di bawah bimbingan guru. Tanpa guru, sulit bagi siswa untuk memperoleh ilmu dengan benar dan benar. Inilah mengapa status guru dalam Islam sangat istimewa. Bahkan dalam tradisi Sufi / Trikat, ada ungkapan yang terkenal: "siapa yang belajar tanpa guru, maka gurunya adalah setan".

Al-Ghazali menggambarkan kedudukan guru agama sebagai berikut: "Makhluk di atas bumi yang paling utama adalah manusia, bagian manusia yang paling utama adalah hatinya. Seorang guru sibuk menyempurnakan, memperbaiki, membersihkan dan mengarahkannya agar dekat kepada Allah azza wajalla. Maka mengajarkan ilmu merupakan ibadah dan merupakan pemenuhan tugas dengan khalifah Allah. Bahkan merupakan tugas kekhalifahan Allah yang paling utama. Sebab Allah telah membukakan untuk hati seorang alim suatu pengetahuan, sifat-Nya yang paling istimewa. Ia bagaikan gudang bagi benda-benda yang paling berharga. Kemudian ia diberi izin untuk memberikan kepada orang yang membutuhkan. Maka derajat mana yang lebih tinggi dari seorang hamba yang menjadi perantara antara Tuhan dengan makhluk-Nya daam mendekatkan mereka kepada Allah dan menggiring mereka menuju surga tempat peristirahatan abadi."'

Kedudukan guru yang istimewa, ternyata berimbang dengan tugas dan tanggungjawabnya yang

${ }^{7}$ Fathiyah Hasan Sulaiman, Konsep Pendidikan Al-Ghazali, terj. Ahmad Hakim dan Imam Azis (Jakarta : P3M, 1990), hal. 41-42. 
tidak ringan. Seorang guru agama bukan hanya guru, tapi juga pendidik. Sebagai pendidik, guru memiliki kewajiban untuk mencapai tujuan pendidikan Islam, yaitu memberikan peran maksimal kepada siswa dan menjadikan mereka muslim yang sempurna. Untuk mencapai tujuan tersebut, guru harus bekerja keras dengan berbagai cara, seperti mengajar, melatih, membiasakan, memberi teladan, memberi semangat, pujian, hukuman bahkan doa. Cara-cara tersebut harus dilakukan dengan hati-hati dan konsisten.

2. Kode Etik Profesi Guru dalam Perspektif Islam

Kode etika adalah mengatur hubungan interpersonal antara pendidik dan peserta didik, antara pendidik dengan orang tua peserta didik, antara pendidik dan pendidik, serta antara atasannya. Norma tersebut berdasarkan pada etika lembaga tersebut.

Profesionalisme menekankan penguasaan keterampilan ilmiah atau manajemen dan strategi implementasinya. Profesi guru tidak hanya pengetahuan teknis dan manajemen, tetapi juga sikap. Pengembangan profesional tidak hanya sebagai tenaga teknis, tidak hanya memiliki keterampilan tinggi, tetapi juga memiliki perilaku yang esensial. ${ }^{8}$ Kode etik guru di tengah-tengah para muridnya, antara lain:

a. Guru hendaknya mengajar dengan niat mengharapkan ridha Allah SWT, menyebarkan ilmu, menegakkan kebenaran.

b. Guru hendaknya tidak menolak untuk mengajar murid yang tidak mempunyai niat tulus dalam belajar.

8 Siswanto, Etika Profesi Guru Pendidikan Agama Islam, (Liai Penerbiao CV. Salsabila putra pratama 2013), hal. 83. 
c. Guru hendaknya mencintai muridnya seperti ia mencintai dirinya sendiri. Artinya, seorang guru hendaknya menganggap bahwa muridnya itu adalah merupakan bagian dari dirinya sendiri.

d. Guru hendaknya memotivasi murid untuk menuntut ilmu seluas mungkin.

e. Guru hendaknya menyampaikan pelajaran dengan bahasa yang mudah dan berusaha agar muridnya dapat memahami pelajaran.

f. Guru hendaknya mengadakan evaluasi terhadap kegiatan belajar mengajar yang dilakukannya. Hal ini dimaksudkan agar guru selalu memperhatikan tingkat pemahaman siswanya dan pertambahan keilmuan yang diperolehnya.

g. Guru hendaknya bersikap adil terhadap semua muridnya.

h. Guru hendaknya berusaha membantu kemaslahatan murid, baik dengan kedudukan maupun hartanya.

i. Guru hendaknya terus memantau perkembangan murid, baik intelektual maupun akhlaknya. Murid yang shaleh akan menjadi tabungan bagi guru, baik di dunia maupun di akhirat.

Agar proses pendidikan dapat berjalan dengan lancar, guru juga harus memiliki ciri utama, yaitu wibawa atau martabat. Wewenang, yaitu pengaruh normatif yang positif pada orang lain atau siswa, tujuannya adalah agar personil yang bersangkutan dapat mengembangkan diri semaksimal mungkin.

Sebagai salah satu cabang ilmu agama Islam, membicarakan etika dalam Islam tidak lepas dari ilmu akhlak. Oleh karena itu, etika Islam dapat dikatakan

${ }^{9}$ A. Haris Hermawan, Filsafat Pendidikan Islam (Jakarta: Direktorat Jenderal Pendidikan Islam Departemen Agama RI, 2009), hlm. 149. 
identik dengan ilmu akhlak, yaitu ilmu tentang keutamaan-keutamaan dan bagaimana cara mendapatkannya agar manusia berhias dengannya, ilmu tentang hal-hal yang hina dan bagaimana cara menjauhinya agar manusia terbebas darinya. Etika dalam Islam sering disebut sebagai falsafah Akhlaqiyyah. Pada dasarnya etika pendidik adalah norma yang mengatur hubungan interpersonal antara pendidik dan peserta didik. $^{10}$

Sebagaimana disebutkan di atas, etika atau sifat dasar guru secara kasar dapat dibagi menjadi dua bagian. Pertama, sifat yang berkaitan dengan kepribadian; kedua, sifat yang berkaitan dengan keahlian akademis. Kedua ciri inilah yang akan membentuk karakter seorang guru yang memiliki kepribadian dan kematangan moral serta memiliki spesialisasi dalam bidang keilmuannya. Guru harus mampu menarik perhatian siswa, membuat mereka tetap terbuka dan mengembangkan pikirannya sendiri. Guru harus terbiasa dengan perilaku siswa yang baik dan memberi contoh, daripada mengajar mereka dengan katakata. $^{11}$

3. Integralitas Konsep Iman, Islam dan Ihsan sebagai Manifestasi Kepribadian Utuh Guru PAI

Kata Iman berasal dari Bahasa Arab yaitu bentuk masdar dari kata kerja (fi'il) amana- yu'minu- iimaanan yang mengandung beberapa arti yaitu percaya, tunduk, tentram dan tenang. Imam Al-Ghazali memaknakannya dengan kata tashdiq yang berarti "pembenaran".

${ }^{10}$ Muhaimin Abdul Mujit, Pemikiran Pendidikan Islam, (Jakarta, Balai Pustaka: 2010), hal. 68.

11 Husayn Ahmad Amin, Seratus Tokoh dalam Sejarah Islam (Bandung: Remaja Rosdakarya, 1997), hal. 243-244. 
Pengertian Iman adalah membenarkan dengan hati, diikrarkan dengan lisan dan dilakukan dengan perbuatan.

Menurut pengertian istilah Islam yaitu untuk mencapai perdamaian dan keamanan senantiasa menjalankan perintah dan menjauhi larangan Allah SWT, serta sikap hamba yang taat dan tunduk kepada Allah SWT, demi mencapai kedamaian dan keselamatan hidup, di dunia maupun di akhirat. Padahal ihsan bisa diartikan sebagai perbuatan baik dalam arti bahasa. Ihsan memiliki satu rukun yaitu engkau beribadah kepada Allah swt seakan-akan engkau melihat-Nya, jika engkau tidak melihat-Nya, maka sesungguhnya Dia melihatmu. Hal ini berdasarkan hadits yang diriwayatkan dari Umar bin Khathab Radhiyallahu 'anhu dalam kisah jawaban Nabi saw kepada Jibril ketika ia bertanya tentang ihsan, maka Nabi shallallahu 'alaihi wa sallam menjawab: "Engkau beribadah kepada Allah seolah-olah engkau melihat-Nya, maka bila engkau tidak melihat-Nya, sesungguhnya Allah melihatmu". ${ }^{12}$

Secara teori iman, Islam, dan ihsan dapat dibedakan namun dari segi prakteknya tidak dapat dipisahkan. Satu dan lainnya saling mengisi, iman menyangkut aspek keyakinan dalam hati yaitu kepercayaan atau keyakinan, sedangkan Islam artinya keselamatan, kesentosaan, patuh, dan tunduk dan ihsan artinya selalu berbuat baik karena merasa diperhatikan oleh Allah. Beribadah agar mendapatkan perhatian dari sang Khaliq, sehingga dapat diterima olehnya. Tidak hanya asal menjalankan perintah dan menjauhi laranganNya saja, melainkan berusaha

${ }^{12}$ Nur Hadi, Islam, Iman Dan Ihsan Dalam Kitab Matan Arba‘In AnNawawi: Studi Materi Pembelajaran Pendidikan Islam dalam Perspektif Hadis Nabi SAW, Jurnal Intelektual: Jurnal Pendidikan dan Studi Keislaman, Volume 9, Nomor 1, April 2019, Hal. 4-5. 
bagaimana amal perbuatan itu bisa bernilai plus dihadapan-Nya. Sebagaimana yang telah disebutkan diatas kedudukan kita hanyalah sebagai hamba, budak dari Tuhan, sebisa mungkin kita bekerja, menjalankan perintah-Nya untuk mendapatkan perhatian dan ridhoNya. Inilah hakikat dari ihsan.

Manifestasi iman, islam dan ihsan dalam kepribadian guru PAI bertujuan untuk mengintegrasikan ketiga pilar ini dalam materi ajar yang disampaikan kepada peserta didik. Agar peserta didik setelah mengalami proses pendidikan membuatnya menjadi insan kamil dengan pola takwa. Insan kamil artinya manusia utuh jasmani dan rohani, dapat berkembang secara wajar dan normal karena takwanya. Seorang guru haruslah memiliki kepribadian yang dimiliki akhlak mulia. Tingkat kemuliaan akhlak erat kaitannya dengan tingkat keimanan. Adapun kepribadian islam yang harus dimiliki seorang guru PAI ialah segala bentuk perbuatan dan tingkah laku yang mencerminkan seorang muslim. ${ }^{13}$

\section{Kesimpulan}

Guru PAI adalah pendidik profesional dengan tugas utama mendidik, mengajar, membimbing, mengarahkan, melatih, memberi teladan, menilai dan mengevaluasi peserta didik. Kedudukan guru dalam Islam sangat istimewa. Dalam Islam kedudukan seorang guru adalah setingkat di bawah kedudukan nabi dan rasul. Hal ini karena guru selalu terkait dengan ilmu, sedangkan Islam sangat mengahargai ilmu pengetahuan. Kode etik guru di tengah-tengah para muridnya, antara lain:

13 Rusdiana Navlia Khulaisie, Hakikat Kepribadian Muslim, Seri Pemahaman Jiwa Terhadap Konsep Insan Kamil, Jurnal Reflektika, Vol. 11 No. 11, Januari, 2016, hal. 40-41. 
1. Guru hendaknya mengajar dengan niat mengharapkan ridha Allah SWT, menyebarkan ilmu, menegakkan kebenaran.

2. Guru hendaknya tidak menolak untuk mengajar murid yang tidak mempunyai niat tulus dalam belajar.

3. Guru hendaknya mencintai muridnya seperti ia mencintai dirinya sendiri. Artinya, seorang guru hendaknya menganggap bahwa muridnya itu adalah merupakan bagian dari dirinya sendiri.

4. Guru hendaknya memotivasi murid untuk menuntut ilmu seluas mungkin.

5. Guru hendaknya menyampaikan pelajaran dengan bahasa yang mudah dan berusaha agar muridnya dapat memahami pelajaran.।

6. Guru hendaknya mengadakan evaluasi terhadap kegiatan belajar mengajar yang dilakukannya. Hal ini dimaksudkan agar guru selalu memperhatikan tingkat pemahaman siswanya dan pertambahan keilmuan yang diperolehnya.

7. Guru hendaknya bersikap adil terhadap semua muridnya.

8. Guru hendaknya berusaha membantu kemaslahatan murid, baik dengan kedudukan maupun hartanya.

9. Guru hendaknya terus memantau perkembangan murid, baik intelektual maupun akhlaknya. Murid yang shaleh akan menjadi tabungan bagi guru, baik di dunia maupun di akhirat.

Manifestasi iman, islam dan ihsan dalam kepribadian guru PAI bertujuan untuk mengintegrasikan ketiga pilar ini dalam materi ajar yang disampaikan kepada peserta didik. Agar peserta didik setelah mengalami proses pendidikan membuatnya menjadi insan kamil dengan pola takwa. Insan kamil artinya manusia utuh jasmani dan rohani, dapat berkembang secara wajar dan normal karena takwanya. 
Seorang guru haruslah memiliki kepribadian yang dimiliki akhlak mulia. Tingkat kemuliaan akhlak erat kaitannya dengan tingkat keimanan. Adapun kepribadian islam yang harus dimiliki seorang guru PAI ialah segala bentuk perbuatan dan tingkah laku yang mencerminkan seorang muslim.

\section{Referensi}

Al-Mubarakfuri, Tuhfah al-Ahwadzi Syarh Jami' al-Tirmidi, Juz 7 (Beirut: Dar alFikr, 1979), al-Kitab: al-'Ilm 'an Rasul Allah; al-Bab : Ma Ja'a fî Fadl al-Fiqh 'Ala al'Ibadah.; Nomor hadits: 2825.

Amin, Husayn Ahmad. 1997. Seratus Tokoh dalam Sejarah Islam Bandung: Remaja Rosdakarya

Hadi Nur. 2019. Islam, Iman Dan Ihsan Dalam Kitab Matan Arba'In An-Nawawi: Studi Materi Pembelajaran Pendidikan Islam dalam Perspektif Hadis Nabi SAW, Jurnal Intelektual: Jurnal Pendidikan dan Studi Keislaman. 9. 1. April (2019)

Hermawan Haris. 2009. Filsafat Pendidikan Islam Jakarta: Direktorat Jenderal Pendidikan Islam Departemen Agama RI

Khulaisie, Rusdiana Navlia. Hakikat Kepribadian Muslim, Seri Pemahaman Jiwa Terhadap Konsep Insan Kamil. Jurnal Reflektika. 11. 11. Januari. (2016)

Marzukhoh Tety dan Mahasri Shobahiya. Studi Komparatif Profil Guru Pendidikan Agama Islam Dalam Perspektif Hasan Langgulung Dan Syed Muhammad Naquib AlAttas, SUHUF. 29. 1. (2017): 39.

Muhadjir Noeng. 2000. Ilmu Pendidikan dan Perubahan Sosial; Teori Pendidikan Pelaku Sosial Kreatif (Yogyakarta : Rake Sarasin) 
Mujit, Muhaimin Abdul. 2010. Pemikiran Pendidikan Islam, Jakarta: Balai Pustaka

Rohani, Imam. Kajian Kebijakan Pendidikan dalam UndangUndang Sistem Pendidikan Nasional. Tarbawi Ngabar: Jurnal of Education, 1 (01), 2020.

Siswanto. 2013. Etika Profesi Guru Pendidikan Agama Islam. (Liai Penerbiao CV. Salsabila putra pratama

Sulaiman, Fathiyah Hasan. 1990. Konsep Pendidikan AlGhazali, terj. Ahmad Hakim dan Imam Azis (Jakarta : P3M)

Tafsir Ahmad. 2004. Ilmu Pendidikan dalam Perspektif Islam (Bandung: PT Rosdakarya

Tim Redaksi. 2005. Kamus Besar Bahasa Indonesia. (Jakarta :

Pusat Bahasa Departemen Pendidikan Nasional-Balai Pustaka) 